\title{
Efficacy of essential oil of Piper aduncum against nymphs and adults of Diaphorina citri
}

\author{
Haroldo XL Volpe, ${ }^{a *}$ Murilo Fazolin, ${ }^{\mathrm{b}}$ Rafael B Garcia, ${ }^{a}$ Rodrigo F Magnani, ${ }^{\text {a,c }}$ \\ José Carlos Barbosa ${ }^{\mathrm{d}}$ and Marcelo P Miranda ${ }^{\mathrm{a}}$
}

\begin{abstract}
BACKGROUND: Insecticide application is the main way to control Diaphorina citri. However, it causes environmental contamination, has a negative impact on beneficial organisms and leads to psyllid resistance. The essential oil of Piper aduncum has low toxicity towards the environment and contains dillapiol, which has proven to be effective against several crop pests. Here, we studied its efficacy against nymphs and adults of $D$. citri under laboratory conditions. Oils with three concentrations of dillapiol $(69.3,79.9$ and $85.4 \%)$ at $0.5,0.75$ and $1.0 \%$ dilutions plus $0.025 \%$ adjuvant were tested.
\end{abstract}

RESULTS: All treatments caused $90-100 \%$ mortality in nymphs. Topical treatments with oil containing 79.9 and $85.4 \%$ dillapiol at $0.75 \%$ and $1 \%$ dilutions were effective (mortality $\geq 80 \%$ ) in adults. However, the essential oil showed no residual activity against adults (mortality $\leq 30 \%$ ).

CONCLUSIONS: Dillapiol-rich oil is a promising compound for $D$. citri control.

(C) 2015 Society of Chemical Industry

Keywords: Asian citrus psyllid; HLB; botanical insecticide; active ingredient rotation; integrated pest management

\section{INTRODUCTION}

Pathogens spread by insect vectors are limiting factors for the cultivation of citrus. In particular, the phloem-infecting bacteria Candidatus Liberibacter asiaticus and $\mathrm{Ca}$. Liberibacter americanus have been associated with the destructive citrus greening disease or huanglongbing (HLB), which affects commercial citrus varieties on the American and Asian continents. ${ }^{1-3}$ The spread of HLB in orchards mainly occurs via the citrus psyllid Diaphorina citri Kuwayama, which has the ability to transmit both bacterial species. ${ }^{4,5}$

Management of HLB includes the use of citrus trees produced in screened vector-free nurseries, inspection and eradication of diseased plants in orchards and control of $D$. citri with applications of insecticides. ${ }^{6}$ Chemical control, mostly by the active ingredient imidacloprid, is the primary method used for management of the insect vector. ${ }^{7,8}$ However, insects have developed resistance against chemicals owing to their frequent use, which leads to a greater selective pressure. In Florida, D. citri was reported to have a resistance ratio higher than 30 for imidacloprid, followed by chlorpyriphosphos (17.9), thiamethoxam (15.0), malathion (5.4) and fenopropathrin (4.8). ${ }^{9}$ The use of different control tactics can slow down the development of resistance and contribute to sustainable use of insecticides in the management of D. citri. ${ }^{8}$

One such alternative that requires additional studies is the use of botanical insecticides. Studies on these insecticides for control of $D$. citri are incipient, and most of them are focused on the use of extract and essential oil of neem (Azadirachta indica A. Juss.). Neem has been demonstrated to have an efficacy against $D$. citri nymphs of $92 \%$ in the greenhouse and approximately $30 \%$ in field conditions. ${ }^{10,11}$ Khan et al. ${ }^{12}$ reported $80 \%$ mortality of adult psyllids in the field using neem extract. Neem and Datura alba Nees extracts reduced the number of $D$. citri nymphs and adults by up to fourfold compared with untreated areas in field conditions. ${ }^{13}$

Piper aduncum L., a plant abundant in the Amazon region, displays insecticidal properties ${ }^{14}$ because it contains secondary metabolites that show toxicity towards insects, especially monoterpenes, ${ }^{15}$ sesquiterpenes ${ }^{16}$ and phenylpropanoids, ${ }^{17}$ with the phenylpropanoid dillapiol being the major compound. ${ }^{18-20}$

Dillapiol potentially inhibits the activity of cytochrome-P450dependent monooxygenase, which transforms lipophilic compounds into more soluble (hydrophilic) and easily excretable products. $^{21}$ Through inhibition of monooxygenase, the ability of the herbivore insect to excrete xenobiotics present in the host plant is reduced, resulting in death owing to the accumulation of toxic substances in its digestive tract. ${ }^{22,23}$ Bernard et al. ${ }^{18}$ observed

Correspondence to: Haroldo XL Volpe, Fundo de Defesa da Citricultura, Av. Dr Adhemar Pereira de Barros, 201, Vila Melhado, s/n, 14807-040, Araraquara, Sao Paulo, Brazil.E-mail: haroldo.volpe@fundecitrus.com.br

a Fundo de Defesa da Citricultura, Araraquara, Sao Paulo, Brazil

b Embrapa Acre, Rio Branco, Acre, Brazil

c Chemistry Department, Federal University of São Carlos, São Carlos, Sao Paulo, Brazil

d Department of Exact Sciences, Faculty of Agricultural and Veterinary Sciences of Jaboticabal - FCAV/Unesp, Jaboticabal, Sao Paulo, Brazil 
a $95 \%$ increased mortality of Ostrinia nubilalis (Hübner) using dillapiol extracted from Piper cubeba L. incorporated into an artificial diet at $100 \mu \mathrm{g} \mathrm{g}^{-1}$. In a study on sucking insects, Silva et al. ${ }^{24}$ reported mortalities of 72 and $80 \%$ for Aetalion sp. adults by using $P$. aduncum extracts from leaves and roots respectively, both at a concentration of $30 \mathrm{mg} \mathrm{mL}^{-1}$. Castro et al..$^{25}$ observed $54.8 \%$ loss of viability in Aleurocanthus woglumi Ashby eggs after topical application of a $4 \%$ aqueous $P$. aduncum leaf extract. Previous studies have determined the insecticidal effect of essential oil of P. aduncum (OPA) on defoliating pests such as Cerotoma tingomarianus Bechyné, ${ }^{26}$ flour pest Tenebrio molitor L. $^{27}$ and stored-grain pest Sitophilus zeamais Motschulsky. ${ }^{28}$ However, currently there are no reports on the toxic activity of $P$. aduncum (dillapiol) towards D. citri.

The objective of the present study was to evaluate the efficacy of dillapiol-rich OPA on nymphs and adults of $D$. citri in our search for a new mode of action to be adopted in the rotation of active ingredients for controlling this insect vector.

\section{EXPERIMENTAL METHODS}

\subsection{OPA extraction and quantification of chemical compounds}

Three-year-old adult $P$. aduncum plants were collected in the production field of Embrapa Acre, Rio Branco, Acre, Brazil $\left(10^{\circ}\right.$ $1^{\prime} 21.36^{\prime \prime} \mathrm{S}, 67^{\circ} 42^{\prime} 31.70^{\prime \prime} \mathrm{W}$ ) by cutting them at $0.4 \mathrm{~m}$ above the ground surface. Plants were harvested every 12 months for essential oil extraction. The leaves and fine stems were separated for processing. The plant mass was subjected to drying to achieve 20-30\% moisture. Essential oil was extracted by steam distillation as described previously ${ }^{29}$ with a yield of around $2-2.5 \%$. The essential oil was redistilled through fractional rectification by using a heating mantle up to $150{ }^{\circ} \mathrm{C}$ and a $3000 \mathrm{~mL}$ flask. The flask was connected to an absorption tower consisting of a single glass column of $50 \times 600 \mathrm{~mm}$ completely filled with $6-8 \mathrm{~mm}$ Raschig rings. The top of the column was connected to a $40 \times 300$ $\mathrm{mm}$ condenser for cooling water circulation to condense the volatiles. The condenser was connected to a fraction collector with a dispensing system under $-760 \mathrm{mmHg}$ pressure created by using a vacuum pump.

For the identification and quantification of chemical compounds, the OPA was analysed using a gas chromatograph (GC) coupled to a GCMS-QP2010 Plus mass spectrometer (MS) (Shimadzu, Tokyo, Japan) equipped with a capillary column (Restek Rxi-5MS, $10 \mathrm{~m} \times 0.10 \mathrm{~mm}$ i.d. $\times 0.10 \mu \mathrm{m}$ film thickness; Restek Corp., Bellefonte, USA). The GC temperature programme consisted of a start temperature of $40^{\circ} \mathrm{C}$, followed by a temperature ramp of $4{ }^{\circ} \mathrm{C} \mathrm{min}-1$ to $190^{\circ} \mathrm{C}$, followed by another ramp of $47^{\circ} \mathrm{C}$ $\mathrm{min}^{-1}$ to $250^{\circ} \mathrm{C}$, and then holding for $1.10 \mathrm{~min}$. This gave a total $\mathrm{GC}$ run time of $40 \mathrm{~min}$. The injector and detector interface temperatures were $250{ }^{\circ} \mathrm{C}$, and the ion source temperature was 200 ${ }^{\circ} \mathrm{C}$; the carrier gas was He (column flow $0.64 \mathrm{~mL} \mathrm{~min}^{-1}$, split ratio $1: 500$ ), and the samples were diluted in methanol (injection of 0.5 $\mu \mathrm{L})$. Mass spectra were recorded at $70 \mathrm{eV}$, with a mass range from $\mathrm{m} / \mathrm{z} 40$ to 350 . Chemical characterisation was performed by comparison of the obtained mass spectra with those available in the GC-MS spectra database from the National Institute of Standards of Technology (NIST), data from the literature and Kovats retention indices. ${ }^{30}$ For determination of Kovats retention rates, a mixture of linear alkanes $\left(C_{8}\right.$ to $\left.C_{20}\right)$ was injected into the chromatograph. ${ }^{31}$ Component relative percentages were calculated on the basis of GC-MS peak areas.
Table 1. Treatments, dilutions and percentage active ingredient for each concentration of mix sprayed on sweet orange (C. sinensis) plants

\begin{tabular}{|c|c|c|}
\hline Treatments & Dilution (v/v) & $\%$ a.i. $L^{-1}$ \\
\hline 1. Control (water) $)^{a, b, c}$ & - & - \\
\hline 2. Control (water + adjuvant $)^{a, b, c}$ & 0.025 & 0.025 \\
\hline 3. OPA $69.3 \%$ dillapiol ${ }^{a, b}$ & 0.5 & 0.3260 \\
\hline 4. OPA $69.3 \%$ dillapiola,b & 0.75 & 0.4890 \\
\hline 5. OPA $69.3 \%$ dillapiol ${ }^{a, b, c}$ & 1.00 & 0.6520 \\
\hline 6. OPA $79.9 \%$ dillapiola,b & 0.5 & 0.383 \\
\hline 7. OPA $79.9 \%$ dillapiola,b & 0.75 & 0.5745 \\
\hline 8. OPA $79.9 \%$ dillapiol ${ }^{a, b}, c$ & 1.00 & 0.766 \\
\hline 9. OPA 85.4\% dillapiol ${ }^{a, b}$ & 0.5 & 0.408 \\
\hline 10. OPA $85.4 \%$ dillapiol ${ }^{a, b}$ & 0.75 & 0.6120 \\
\hline 11. OPA $85.4 \%$ dillapiol ${ }^{a, b, c}$ & 1.0 & 0.8160 \\
\hline 12. Dillapiol $99.5 \%^{\mathrm{a}}$ & 0.5 & 0.5 \\
\hline 13. Dillapiol $99.5 \%^{\mathrm{a}}$ & 0.75 & 0.75 \\
\hline 14. Dillapiol $99.5 \%^{\mathrm{a}}$ & 1.00 & 1.00 \\
\hline 15. Imidacloprid ${ }^{\mathrm{b}, \mathrm{c}}$ & 0.004 & 20.0 \\
\hline \multicolumn{3}{|c|}{$\begin{array}{l}\text { a Phytotoxicity against } C \text {. sinensis. } \\
\text { b Topical application on nymphs and adults of } D \text {. citri. } \\
\text { c Residual application on adults of } D \text {. citri. }\end{array}$} \\
\hline
\end{tabular}

\subsection{Phytotoxicity of the OPA against Citrus sinensis and definition of working concentrations}

Before selecting the range of OPA concentrations to assess its efficacy against $D$. citri nymphs and adults, we evaluated the phytotoxic effect on sweet orange shoots using three dilutions with four different concentrations. The experiment was carried out at Fundecitrus (Fundo de Defesa da Citricultura), Araraquara, Sao Paulo, Brazil ( $\left.21^{\circ} 48^{\prime} 32.35^{\prime \prime} \mathrm{S}, 48^{\circ} 9^{\prime} 50.82^{\prime \prime} \mathrm{W}\right)$ in a greenhouse $(1.60 \times 7.90 \times 6.0 \mathrm{~m})$ under ambient temperature (average temperature $27.13^{\circ} \mathrm{C}$ ) and relative humidity (average $\mathrm{RH} 71.62 \%$ ) for the entire experimental period.

Forty-two nursery trees \{one-year-old Citrus sinensis (L.) Osbeck var. Valencia grafted on Swingle citrumelo [Citrus paradisi Macf. $\times$ Poncirus trifoliata (L.) Raf.]\} with three $15-18 \mathrm{~cm}$ young shoots per grafted tree were selected. The plants were grown in $20 \mathrm{~L}$ pots containing substrate ( $80 \%$ Pinus sp. bark, $15 \%$ vermiculite and $5 \%$ charcoal) (Multiplant Citrus ${ }^{\circledR}$; Terra do Paraíso, Holambra, Sao Paulo, Brazil).

For the preparation of the insecticide sprays, OPA with different concentrations of dillapiol (69.3, 79.9 and 85.4\%) and dillapiol $99.5 \%$ were diluted to $0.5,0.75$ and $1.0 \% \mathrm{v} / \mathrm{v}$ in water, with the addition of $0.025 \%$ Silwet ${ }^{\circledR}$ adjuvant (polyester copolymer and silicone at 100\%) (Momentive, Itatiba, Sao Paulo, Brazil). The sprays were prepared by diluting the adjuvant in water and then adding the OPA according to the concentrations established for each treatment. In addition, two control treatments consisting of pure water and water with $0.025 \%$ adjuvant were included (Table 1 ). The young shoots were sprayed to a point just before run-off (7.0 $\mathrm{mL}$ ) with the aid of a Brudden ${ }^{\circledR}$ S-600 manually operated sprayer (Brudden, Pompéia, Sao Paulo, Brazil).

Phytotoxicity was visually assessed in the young shoots at 1, 7 and 15 days after application (DAA) and scored as follows: score 0 (no toxicity), asymptomatic plants; score 1 (mild toxicity), plants with up to $1 \mathrm{~mm}$ necrotic spots (burning) on the leaves; score 2 (moderate toxicity), plants with 1-3 $\mathrm{mm}$ spots on the leaves and branches; score 3 (high toxicity), plants with necrotic spots 
larger than $3 \mathrm{~mm}$ on the leaves and/or complete necrosis of young shoots. We used a randomised block experimental design with 14 treatments and nine replications. Each treatment consisted of three nursery citrus trees containing three young shoots each; each shoot was considered to be a replicate.

For efficacy studies on $D$. citri, doses that caused no or mild phytotoxicity (scores 0 and 1 ) or that induced moderate toxicity (score 2 ) in up to $30 \%$ of the plants were selected. The treatments that resulted in more than $30 \%$ of plants with score 2 and highly phytotoxic treatments (score 3 ) were excluded from these experiments.

\subsection{Assessment of the efficacy of the OPA against $D$. citri 2.3.1 Insects, plants and testing conditions}

The insects were obtained from a $D$. citri rearing established at Fundecitrus. The rearing was maintained on Murraya paniculata (L.) in a climatised room (temperature $25 \pm 3{ }^{\circ} \mathrm{C}$, photoperiod 14 h, relative humidity $65 \pm 10 \%$ ). To obtain eggs, plants with young shoots were transferred to acrylic cages $(20 \times 21 \times 55 \mathrm{~cm})$ with an anti-aphid screen and exposed to adults for 7 days. The plants containing eggs were kept in the cages until the emergence of adults. To evaluate the efficacy of the OPA, seedlings of $C$. sinensis var. Caipira, grown in tubes in screened nurseries, were used. All tests were conducted in the laboratory under the same temperature, photoperiod and relative humidity conditions as described for the rearing of psyllids.

\subsubsection{Assessment of the efficacy of the OPA on D. citri nymphs and adults by topical application}

The OPA treatments used in these experiments were selected on the basis of phytotoxicity test results (Section 2.2). We used treatment with imidacloprid (Provado ${ }^{\circledR} 200$ SC; Bayer CropScience AG, Belford Roxo, Brazil) as a positive control (Table 1). To test the efficacy of OPA against nymphs, each seedling with one young shoot was infested with ten third-instar nymphs with the aid of a soft paintbrush. The infested plants were subjected to the various OPA spray treatments and maintained in a climatised room. To test the efficacy of OPA against adults, ten insects at 10 days after emergence were confined on each shoot by using sleeve cages that were pervious to spraying and that covered the whole shoot. The shoots were sprayed until product run-off. The same treatments as described for topical application on nymphs were used (Table 1).

The number of dead insects (nymphs or adults) was counted at 1, 3 and 7 DAA. Nymphs and adults were considered to be dead when they did not present mobility of legs, wings and antennae. For nymphs, the efficacy of the OPA was tested only for topical application on account of the fact that, after outbreak, the nymphs develop on the same branch until the emergence of adults, not justifying the testing of residual contact. For both tests, a completely randomised block design was used, and each seedling represented a replicate. Seven plants were used for the experiment with nymphs, and eight for the experiment with adults. Additionally, a $3 \times 3$ factorial design (concentrations of dillapiol $\times$ dilutions of OPA used) was used for the adult insects to verify whether there was an influence of increasing dillapiol/OPA and OPA/dillapiol concentration ratios on insect mortality.

\subsubsection{Assessment of the efficacy of the OPA on adults of D. citri by residual contact}

Ten adults at 10 days after emergence were placed on the shoot of each seedling on the dry residue ( $2 \mathrm{~h}$ after spraying), using the same insect confinement method and spray application as described above. The treatments used in this test were those classified as effective in the topical application test (mortality $\geq 80 \%$ ) (Table 1), as described in Section 2.3.2. The assessments and experimental design were similar to those of the topical tests.

\subsection{Data analysis and statistics}

The results of the assessment of the phytotoxic effect were expressed as percentages calculated from the scores attributed to the damage in all young shoots per treatment. The number of dead insects for all efficacy tests was expressed as a percentage. All data were expressed as the mean \pm standard error of the mean (SE). The data were transformed into arcsine $(x / 100)^{0.5}$ prior to analysis to reduce heteroscedasticity and achieve normality. Means were subjected to analysis of variance (ANOVA) with repeated measures over time, and, in case of significance, compared by Tukey's test $(P \leq 0.05)$. All analyses were performed using the AgroEstat software. ${ }^{32}$

\section{RESULTS}

\subsection{Chemical constituents of essential oils}

The compositions of the four OPAs obtained by fractional distillation used in the present experiments were determined by GC-MS, comparing their relative retention times and the mass spectra of the OPA components from a data library. We injected three samples from each OPA fraction to determine the average percentage \pm SE for each fraction of oil. Characterised compounds of these oils with their relative percentages are listed in Table 2. A total of 40, 39, 30 and six components were identified in OPA 01, OPA 02, OPA 03 and OPA 04 respectively. Six compounds comprising myristicin, $z$-isoelemicin, caryophyllene oxide, globulol, dillapiol and apiol were present in all four OPAs. Dillapiol was the most abundant compound identified from OPAs obtained by fractional distillation, and the percentages were $69.3,79.9,85.4$ and $99.5 \%$. The different OPA fractions are termed OPA-69.3, OPA-79.9, OPA-85.4 and dillapiol-99.5 hereafter, for OPA 1, 2, 3 and 4 respectively, considering the percentage of dillapiol in the obtained fractions.

\subsection{Phytotoxicity of OPA against $C$. sinensis and definition of working concentrations}

The proportion of plants with the same degree of toxicity observed in the first assessment (1 DAA) remained constant during the entire experimental period.

Treatment of $C$. sinensis plants with OPA-69.3 at dilutions of 0.75 and $1.0 \%$, with OPA-79.9 at $0.75 \%$ dilution and with OPA-85.4 at dilutions of $0.5,0.75$ and $1.0 \%$ caused no phytotoxic effect in $100 \%$ of the plants. OPA- 69.3 at $0.5 \%$ was non-toxic to $88.88 \%$ of the plants, and OPA-79.9 at 0.5 and $1.0 \%$ was non-toxic for $66.6 \%$ and $33.33 \%$ of the plants respectively.

OPA- 69.3 at $0.5 \%$ caused mild toxicity to $11.11 \%$ of the plants, and OPA-79.9 at 0.5 and $1.0 \%$ caused mild toxicity to 22.22 and $33.33 \%$ of the plants respectively.

OPA-79.9 at 0.5 and $1.0 \%$ was moderately toxic to 11.18 and $33.33 \%$ of the plants respectively, while dillapiol-99.5 at 0.5 and $1.0 \%$ caused moderate toxicity to $33.66 \%$ of the plants. Dillapiol-99.5 at $0.75 \%$ caused moderate toxicity to $66.66 \%$ of the plants.

Only dillapiol-99.5 was highly toxic to plants. The 0.5 and $1.0 \%$ dilutions were highly toxic to $66.6 \%$ of the plants, while the $0.75 \%$ dilution caused high toxicity to $33.33 \%$ of the plants. The two 


\begin{tabular}{|c|c|c|c|c|c|c|}
\hline \multirow[b]{2}{*}{ Compound } & \multirow[b]{2}{*}{$\mathrm{RT}^{\mathrm{a}}(\min )$} & \multirow[b]{2}{*}{$\mathrm{Rl}^{\mathrm{b}}$} & \multicolumn{4}{|c|}{ Relative area $(\% \pm \mathrm{SE})^{\mathrm{c}}$} \\
\hline & & & OPA 1 & OPA 2 & OPA 3 & OPA 4 \\
\hline$\alpha$-Pinene & 3.123 & 917 & $1.08 \pm 0.07$ & $0.55 \pm 0.04$ & $\operatorname{tr}$ & - \\
\hline Camphene & 3.385 & 931 & $\operatorname{tr}^{d}$ & $\operatorname{tr}$ & - & - \\
\hline$\beta$-Pinene & 3.957 & 962 & $1.92 \pm 0.09$ & $1.01 \pm 0.06$ & $\operatorname{tr}$ & - \\
\hline Myrcene & 4.422 & 986 & $\operatorname{tr}$ & $\operatorname{tr}$ & - & - \\
\hline$\alpha$-Phellandrene & 4.634 & 997 & $0.90 \pm 0.04$ & $0.30 \pm 0.03$ & - & - \\
\hline$p$-Cymene & 5.149 & 1018 & $\operatorname{tr}$ & $\operatorname{tr}$ & - & - \\
\hline Limonene & 5.241 & 1021 & $0.48 \pm 0.02$ & $0.17 \pm 0.00$ & - & - \\
\hline (Z)- $\beta$-Ocimene & 5.616 & 1035 & $0.79 \pm 0.02$ & $0.21 \pm 0.01$ & - & - \\
\hline$(E)$ - $\beta$-Ocimene & 5.878 & 1045 & $1.87 \pm 0.05$ & $0.46 \pm 0.03$ & - & - \\
\hline Terpinolene & 6.886 & 1083 & $\operatorname{tr}$ & $\operatorname{tr}$ & - & - \\
\hline$\alpha$-Cubebene & 14.907 & 1342 & $0.10 \pm 0.00$ & $\operatorname{tr}$ & $\operatorname{tr}$ & - \\
\hline$\alpha$-Longipinene & 15.193 & 1351 & $\operatorname{tr}$ & $\operatorname{tr}$ & $\operatorname{tr}$ & - \\
\hline Cyclosativene & 15.297 & 1354 & $0.17 \pm 0.01$ & $0.12 \pm 0.00$ & $\operatorname{tr}$ & - \\
\hline$\alpha$-Copaene & 15.634 & 1365 & $0.98 \pm 0.01$ & $0.73 \pm 0.01$ & $0.63 \pm 0.01$ & - \\
\hline$\beta$-Cubebene & 16.127 & 1381 & $\operatorname{tr}$ & $\operatorname{tr}$ & - & - \\
\hline$\beta$-Elemene & 16.203 & 1383 & $0.27 \pm 0.00$ & $\operatorname{tr}$ & $0.10 \pm 0.01$ & - \\
\hline$\alpha$-Gurjunene & 16.620 & 1397 & $0.19 \pm 0.00$ & $\operatorname{tr}$ & $\operatorname{tr}$ & - \\
\hline (E)-Caryophyllene & 16.879 & 1405 & $10.44 \pm 0.12$ & $7.14 \pm 0.08$ & $4.85 \pm 0.06$ & - \\
\hline$\alpha$-Santalene & 17.058 & 1411 & $0.19 \pm 0.01$ & $0.14 \pm 0.00$ & $0.10 \pm 0.01$ & - \\
\hline$\beta$-Copaene & 17.196 & 1416 & $\operatorname{tr}$ & $\operatorname{tr}$ & $\operatorname{tr}$ & - \\
\hline Aromadendrene & 17.441 & 1424 & $0.24 \pm 0.00$ & $0.10 \pm 0.00$ & $\operatorname{tr}$ & - \\
\hline$\alpha$-Humulene & 17.872 & 1439 & $1.40 \pm 0.02$ & $0.93 \pm 0.04$ & $0.68 \pm 0.00$ & - \\
\hline allo-Aromadendrene & 18.084 & 1446 & $0.24 \pm 0.01$ & $0.17 \pm 0.00$ & $0.13 \pm 0.01$ & - \\
\hline Dauca-5,8-diene & 18.583 & 1463 & $0.10 \pm 0.01$ & $\operatorname{tr}$ & $\operatorname{tr}$ & - \\
\hline Germacrene D & 18.720 & 1467 & $0.99 \pm 0.01$ & $0.80 \pm 0.02$ & $0.21 \pm 0.01$ & - \\
\hline Bicyclogermacrene & 19.187 & 1483 & $1.31 \pm 0.02$ & $0.86 \pm 0.01$ & $0.28 \pm 0.01$ & - \\
\hline$\alpha$-Muurolene & 19.412 & 1490 & $0.34 \pm 0.01$ & $0.24 \pm 0.01$ & $0.15 \pm 0.01$ & - \\
\hline$\beta$-Himachalene & 19.595 & 1496 & $0.72 \pm 0.01$ & $0.34 \pm 0.01$ & $0.13 \pm 0.02$ & - \\
\hline$n$-Pentadecane & 19.718 & 1501 & $0.96 \pm 0.03$ & $1.34 \pm 0.01$ & $2.01 \pm 0.10$ & - \\
\hline$\delta$-Amorphene & 19.770 & 1496 & $0.24 \pm 0.01$ & $0.19 \pm 0.01$ & $0.46 \pm 0.05$ & - \\
\hline$\beta$-Curcumene & 19.870 & 1506 & $0.26 \pm 0.00$ & $0.17 \pm 0.00$ & $0.18 \pm 0.00$ & - \\
\hline Myristicin & 20.097 & 1514 & $2.68 \pm 0.01$ & $2.13 \pm 0.02$ & $2.06 \pm 0.04$ & $0.17 \pm 0.02$ \\
\hline$\alpha$-Calacorene & 20.534 & 1529 & $0.15 \pm 0.00$ & $0.12 \pm 0.02$ & $0.30 \pm 0.01$ & - \\
\hline Germacrene B & 20.835 & 1540 & $0.10 \pm 0.00$ & $\operatorname{tr}$ & $\operatorname{tr}$ & - \\
\hline z-Isoelemicin & 21.333 & 1557 & $0.15 \pm 0.00$ & $0.13 \pm 0.01$ & $0.12 \pm 0.01$ & $\operatorname{tr}$ \\
\hline Spathulenol & 21.459 & 1562 & $0.12 \pm 0.01$ & - & - & - \\
\hline Caryophyllene oxide & 21.549 & 1565 & $0.29 \pm 0.01$ & $0.61 \pm 0.03$ & $0.77 \pm 0.04$ & $\operatorname{tr}$ \\
\hline Globulol & 21.822 & 1575 & $0.47 \pm 0.01$ & $0.45 \pm 0.01$ & $0.72 \pm 0.04$ & $\operatorname{tr}$ \\
\hline Dillapiol & 23.128 & 1622 & $69.3 \pm 0.40$ & $79.9 \pm 0.10$ & $85.4 \pm 0.21$ & $99.5 \pm 0.03$ \\
\hline Apiol & 24.570 & 1675 & $0.15 \pm 0.00$ & $0.18 \pm 0.02$ & $0.23 \pm 0.01$ & $0.15 \pm 0.00$ \\
\hline
\end{tabular}

control treatments, with or without adjuvant, were non-toxic to $100 \%$ of the $C$. sinensis plants. Because dillapiol-99.5 presented moderate toxicity to more than $35 \%$ of the plants and was the only treatment that caused high toxicity, it was excluded from the efficacy tests on $D$. citri.

\subsection{Assessment of the efficacy of the OPA against nymphs and adults of $D$. citri by topical contact}

The nymphs of $D$. citri displayed high sensitivity to all treatments containing OPA. The average mortality obtained by the treatments varied between 90.00 and $98.57 \%$ on the first day of assessment (1
DAA), between 91.42 and $100 \%$ at 3 DAA and between 97.14 and $100.0 \%$ in the final assessment (7 DAA) (Table 3). The high mortality (90.00-98.57\%) observed at 1 DAA in all treatments indicates a knockdown effect of the OPA for third-instar nymphs of $D$. citri. The average mortality did not significantly differ among the treatments and compared with the positive control imidacloprid. Only the lowest concentration evaluated, OPA-69.3 at 0.5\%, showed a significantly higher mortality at 7 DAA compared with 1 and 3DAA. However, the average mortality obtained by the treatments significantly differed from the control treatment at all time points (1 DAA: $F=44.10, \mathrm{df}=11, P<0.0001 ; 3 \mathrm{DAA}: F=35.80, \mathrm{df}=11, P<0.0001$; 


\begin{tabular}{|c|c|c|c|c|c|}
\hline \multirow[b]{2}{*}{ Treatments } & \multirow[b]{2}{*}{ Dilution (v/v) } & \multirow[b]{2}{*}{$n$} & \multicolumn{3}{|c|}{ Mortality (\%) } \\
\hline & & & $1 \mathrm{DAA}$ & $3 \mathrm{DAA}$ & $7 \mathrm{DAA}$ \\
\hline Control (water) & - & 7 & $1.42 \pm 1.42 \mathrm{Cb}$ & $10.00 \pm 5.34 \mathrm{Ca}$ & $10.00 \pm 5.34 \mathrm{Ca}$ \\
\hline Control (adj) & 0.025 & 7 & $35.71 \pm 10.43 \mathrm{Bb}$ & $45.71 \pm 10.87 \mathrm{Ba}$ & $47.14 \pm 10.62 \mathrm{Ba}$ \\
\hline OPA 69.3\% dillapiol & 0.5 & 7 & $90.00 \pm 5.34 \mathrm{Ab}$ & $91.42 \pm 5.53 \mathrm{Ab}$ & $97.14 \pm 1.84 \mathrm{Aa}$ \\
\hline OPA 69.3\% dillapiol & 0.75 & 7 & $100.00 \pm 0.00 \mathrm{Aa}$ & $100.00 \pm 0.00 \mathrm{Aa}$ & $100.00 \pm 0.00 \mathrm{Aa}$ \\
\hline OPA $69.3 \%$ dillapiol & 1.00 & 7 & $95.71 \pm 2.97 \mathrm{Aa}$ & $97.14 \pm 1.84 \mathrm{Aa}$ & $98.57 \pm 0.00 \mathrm{Aa}$ \\
\hline OPA $79.9 \%$ dillapiol & 0.5 & 7 & $94.28 \pm 5.71 \mathrm{Aa}$ & $97.14 \pm 2.85 \mathrm{Aa}$ & $97.14 \pm 2.85 \mathrm{Aa}$ \\
\hline OPA 79.9\% dillapiol & 0.75 & 7 & $98.57 \pm 1.42 \mathrm{Aa}$ & $100.00 \pm 0.00 \mathrm{Aa}$ & $100.00 \pm 0.00 \mathrm{Aa}$ \\
\hline OPA $79.9 \%$ dillapiol & 1.00 & 7 & $97.14 \pm 2.85 \mathrm{Aa}$ & $97.14 \pm 2.85 \mathrm{Aa}$ & $97.14 \pm 2.85 \mathrm{Aa}$ \\
\hline OPA $85.4 \%$ dillapiol & 0.5 & 7 & $97.14 \pm 2.85 \mathrm{Aa}$ & $97.14 \pm 2.85 \mathrm{Aa}$ & $97.14 \pm 2.85 \mathrm{Aa}$ \\
\hline OPA $85.4 \%$ dillapiol & 0.75 & 7 & $91.42 \pm 8.57 \mathrm{Aa}$ & $91.42 \pm 8.57 \mathrm{Aa}$ & $91.42 \pm 8.57 \mathrm{Aa}$ \\
\hline OPA 85.4\% dillapiol & 1.00 & 7 & $98.57 \pm 1.42 \mathrm{Aa}$ & $100.00 \pm 0.00 \mathrm{Aa}$ & $100.00 \pm 0.00 \mathrm{Aa}$ \\
\hline Imidacloprid & 0.004 & 7 & $100.00 \pm 0.00 \mathrm{Aa}$ & $100.00 \pm 0.00 \mathrm{Aa}$ & $100.00 \pm 1.42 \mathrm{Aa}$ \\
\hline
\end{tabular}

\begin{tabular}{|c|c|c|c|c|c|}
\hline \multirow[b]{2}{*}{ Treatments } & \multirow[b]{2}{*}{ Concentration (v/v) } & \multirow[b]{2}{*}{$n$} & \multicolumn{3}{|c|}{ Mortality (\%) } \\
\hline & & & $1 \mathrm{DAA}$ & 3 DAA & $7 \mathrm{DAA}$ \\
\hline Control (water) & - & 8 & $1.25 \pm 1.25 \mathrm{Da}$ & $2.50 \pm 1.63 \mathrm{Ea}$ & $6.25 \pm 2.63 \mathrm{Da}$ \\
\hline Control (adj) & 0.025 & 8 & $5.00 \pm 2.67 \mathrm{Da}$ & $11.25 \pm 4.79 \mathrm{Ea}$ & $13.75 \pm 4.60 \mathrm{Da}$ \\
\hline OPA 69.3\% dillapiol & 0.5 & 8 & $33.75 \pm 12.94 \mathrm{BCDa}$ & $36.25 \pm 13.22 \mathrm{DEa}$ & $43.75 \pm 12.94 \mathrm{BCDa}$ \\
\hline OPA 69.3\% dillapiol & 0.75 & 8 & $16.25 \pm 7.54 \mathrm{CDa}$ & $17.50 \pm 7.73 \mathrm{DEa}$ & $21.25 \pm 7.42 \mathrm{Da}$ \\
\hline OPA $69.3 \%$ dillapiol & 1.00 & 8 & $46.25 \pm 14.99 \mathrm{BCb}$ & $55.00 \pm 14.26 \mathrm{CDb}$ & $70.00 \pm 10.00 \mathrm{ABa}$ \\
\hline OPA $79.9 \%$ dillapiol & 0.5 & 8 & $20.00 \pm 9.25 \mathrm{CDb}$ & $25.00 \pm 9.06$ DEab & $33.75 \pm 9.43 \mathrm{BCDa}$ \\
\hline OPA $79.9 \%$ dillapiol & 0.75 & 8 & $72.50 \pm 11.76 \mathrm{ABb}$ & $78.75 \pm 10.92 \mathrm{ABCab}$ & $86.25 \pm 9.80 \mathrm{Aa}$ \\
\hline OPA $79.9 \%$ dillapiol & 1.00 & 8 & $88.75 \pm 6.39 \mathrm{Aa}$ & $95.00 \pm 3.77 \mathrm{ABCa}$ & $96.25 \pm 2.63 \mathrm{Aa}$ \\
\hline OPA 85.4\% dillapiol & 0.5 & 8 & $5.00 \pm 3.77 \mathrm{Db}$ & $13.75 \pm 7.05 \mathrm{Eab}$ & $22.50 \pm 8.60 \mathrm{CDa}$ \\
\hline OPA 85.4\% dillapiol & 0.75 & 8 & $36.25 \pm 10.84 \mathrm{BCDb}$ & $57.50 \pm 13.59 \mathrm{BCDa}$ & $62.50 \pm 13.59 \mathrm{ABCa}$ \\
\hline OPA $85.4 \%$ dillapiol & 1.00 & 8 & $96.25 \pm 3.75 \mathrm{Aa}$ & $97.50 \pm 2.50 \mathrm{ABa}$ & $98.75 \pm 1.25 \mathrm{Aa}$ \\
\hline Imidacloprid & 0.004 & 8 & $95.00 \pm 3.77 \mathrm{Aa}$ & $98.75 \pm 1.25 \mathrm{Aa}$ & $100.00 \pm 0.00 \mathrm{Aa}$ \\
\hline
\end{tabular}

${ }^{a}$ Means followed by the same upper-case letter in a column and by the same lower-case letter in a row do not differ according to Tukey's test $(P \leq 0.05)$.

7DAA: $F=35.87, \mathrm{df}=11, P<0.0001)$. The mortality induced by the control with adjuvant was significantly higher than that caused by the control containing water alone at all time points (Table 3 ).

In adults, OPA-79.9 at 0.75 and $1.0 \%$ dilutions and 1.0\% OPA-85.4 induced the highest mortality $(>72.5 \%)$ at 1 DAA, indicating a knockdown effect. The effects did not differ from those obtained with imidacloprid, but were significantly different from those with the controls $(F=18.21, \mathrm{df}=11, P<0.0001)$. In the adult insects, the effect of the control containing water alone did not differ significantly from that of the control containing adjuvant. Treatment with OPA-69.3 at a concentration of $1.0 \%$ showed intermediate efficacy; the mortality was significantly higher than that induced by the control (46.25\%), but lower than that induced by imidacloprid and the higher OPA concentrations $(F=18.21, \mathrm{df}=11$, $P<0.0001)$. The other treatments did not differ from the controls (Table 4). At 3 DAA, OPA-79.9 at 0.75 and $1.0 \%$ dilutions and the $1.0 \%$ OPA-85.4 dilution sustained the efficacy observed in the first assessment, displaying higher values of mortality (78.75-97.50\%). Again, the effects did not differ from those obtained with imidacloprid, but were significantly different from those with the controls $(F=18.19, \mathrm{df}=11, P<0.0001)$. The efficacies of OPA- 69.3 at $1.0 \%$ and OPA- 85.4 at $0.75 \%$ were intermediate, as they caused significantly higher mortality (55 and $57.50 \%$ respectively) compared with the controls (2.5\%), but were less effective than imidacloprid (98.75\%) (Table 4).

At 7 DAA, OPA-69.3 at 1.0\%, OPA-79.9 at 0.75 and $1.0 \%$ and OPA-85.4 at 0.75 and $1.0 \%$ did not significantly differ from imidacloprid, with the average mortality ranging between 62.5 and 96.25\%; however, they significantly differed from the controls $(F=17.25, \mathrm{df}=11, P<0.0001)$ (Table 4). The other treatments did not significantly differ from the controls (Table 4).

Comparison of the mortality caused at different time points by each treatment revealed that the mortality did not significantly differ between the time points for 1\% OPA-79.9 $(F=1.75, \mathrm{df}=2$, $P=0.1767)$ and $1 \%$ OPA-85.4 $(F=0.17, \mathrm{df}=2, P=0.8443)$. These treatments induced high mortality in $D$. citri adults ( $>88.75 \%)$ at $1 \mathrm{DAA}$, not significantly differing from the other time points of assessment. In contrast, the effects of OPA- 69.3 at $1.0 \%$ and 
Table 5. Influence of the concentration of dillapiol and dilution of the essential oil of Piper aduncum on the percentage mortality ( \pm SEM) of Diaphorina citri adults in topical application ${ }^{\mathrm{a}}$

\begin{tabular}{lllll} 
& & & \multicolumn{3}{c}{ Essential oil (v/v) } \\
\cline { 3 - 5 } Dillapiol (\%) & $n$ & \multicolumn{1}{c}{0.5} & 0.75 & 1.00 \\
69.3 & 8 & $43.75 \pm 12.94 \mathrm{Aab}$ & $21.25 \pm 7.42 \mathrm{Bb}$ & $70.00 \pm 10.00 \mathrm{Ba}$ \\
79.9 & 8 & $33.75 \pm 9.43 \mathrm{Ab}$ & $86.25 \pm 9.80 \mathrm{Aa}$ & $96.25 \pm 2.63 \mathrm{Aa}$ \\
85.4 & 8 & $22.50 \pm 8.60 \mathrm{Ac}$ & $62.50 \pm 13.59 \mathrm{Ab}$ & $98.75 \pm 1.25 \mathrm{Aa}$ \\
\hline
\end{tabular}

a Means followed by the same upper-case letter in a column and by the same lower-case letter in a row do not differ according to Tukey's test $(P \leq 0.05)$. Values in the table correspond to the final time point (7 DAA).

\begin{tabular}{|c|c|c|c|c|c|}
\hline \multirow[b]{2}{*}{ Treatments } & \multirow[b]{2}{*}{ Concentration $(\mathrm{v} / \mathrm{v})$} & \multirow[b]{2}{*}{$n$} & \multicolumn{3}{|c|}{ Mortality (\%) } \\
\hline & & & $1 \mathrm{DAA}$ & 3 DAA & 7 DAA \\
\hline Control (water) & - & 8 & $10.00 \pm 4.62 \mathrm{Ba}$ & $14.28 \pm 4.16 \mathrm{BCa}$ & $17.14 \pm 4.51 \mathrm{BCa}$ \\
\hline Control (adj) & 0.025 & 8 & $0.00 \pm 0.00 \mathrm{Ba}$ & $2.50 \pm 1.63 \mathrm{Ca}$ & $5.00 \pm 3.27 \mathrm{Ca}$ \\
\hline Dillapiol 69.3\% & 1.00 & 8 & $5.00 \pm 1.88 \mathrm{Bb}$ & $10.00 \pm 4.62 \mathrm{BCb}$ & $18.75 \pm 5.49 \mathrm{BCa}$ \\
\hline Dillapiol 79.9\% & 1.00 & 8 & $3.75 \pm 2.63 \mathrm{Bb}$ & $7.50 \pm 4.11 \mathrm{BCb}$ & $17.50 \pm 4.53 \mathrm{BCa}$ \\
\hline Dillapiol 85.4\% & 1.00 & 8 & $16.25 \pm 5.95 \mathrm{Bb}$ & $22.50 \pm 5.59 \mathrm{Bab}$ & $30.00 \pm 8.01 \mathrm{Ba}$ \\
\hline Imidacloprid & 0.004 & 8 & $87.50 \pm 5.26 \mathrm{Ab}$ & $98.75 \pm 1.25 \mathrm{Aa}$ & $100.00 \pm 0.00 \mathrm{Aa}$ \\
\hline
\end{tabular}

${ }^{a}$ Means followed by the same upper-case letter in a column and by the same lower-case letter in a row do not differ according to Tukey's test $(P \leq 0.05)$.

OPA-79.9 at $0.75 \%$ significantly increased over the experimental period, as indicated by the increasing mortality $(F=15.67, \mathrm{df}=2$, $P<0.0001$ and $F=5.14, \mathrm{df}=2, P=0.0068$ respectively), indicating the occurrence of a lethal action after a longer period, which may be considered to be an intermediate effect in comparison with more effective treatments. The 0.5\% OPA-79.9 and OPA-85.4 treatments also displayed a significant increase in efficacy, as indicated by the significantly increased mortality, during the experimental period $(F=5.25, \mathrm{df}=2, P=0.0061$ and $F=8.30, \mathrm{df}=2, P=0.004)$; however, their efficacy remained low in the final assessment (mortality <50\%) (Table 4).

Next, we tested the interactions between the concentration of dillapiol in the OPA and the dilutions used in the treatments. An increase in dillapiol content was reflected in a higher mortality of adults for the $0.75 \%$ dilution $(F=11.05, \mathrm{df}=2, P<0.0001)$ and the $1 \%$ dilution $(F=9.88, \mathrm{df}=2, P=0.0001$ ). However, for the $0.5 \%$ dilution, no significant difference in mortality in $D$. citri adults was observed ( $F=2.81, \mathrm{df}=2, P=0.0659$ ) with increasing dillapiol content in the diluted oil extracts (Table 5). When comparing the effects of different concentrations of dillapiol for each oil extract dilution, we observed that OPA-69.3 caused significantly higher mortality at dilutions of 0.5 and $1.0 \%$, but no significant difference was noted between 0.5 and $0.75 \%(F=3.09$, df $=2, P=0.0509)$. OPA-79.9 caused significantly higher mortality at dilutions of 0.75 and $1.0 \%$ than at $0.5 \%$ dilution $(F=17.54$, df $=2, P<0.0001)$. Finally, OPA-85.4 caused significantly increased mortality with each decrease in dilution $(F=29.22, \mathrm{df}=2, P<0.0001$ ) (Table 5).

\subsection{Assessment of the residual efficacy of the OPA on D. citri adults}

The residual efficacy of all the treatments against adult $D$. citri, regardless of the concentration of dillapiol in the OPA and the dilution used, was significantly lower than that of imidacloprid at 1,3 and 7 DAA $(F=60.20, \mathrm{df}=5, P<0.0001 ; F=71.40, \mathrm{df}=5$, $P<0.0001 ; F=64.56, \mathrm{df}=5, P<0.0001$ respectively). The treatments with OPA showed a significant increase in mortality over the assessment period $(F=9.34, \mathrm{df}=2, P=0.0002 ; F=9.74, \mathrm{df}=2$, $P=0.0002 ; F=9.14, \mathrm{df}=2, P=0.0003$ for 1,3 and 7 DAA respectively); however, the efficacy remained low, even at 7 DAA (average mortality $\leq 30 \%$ ) (Table 6).

\section{DISCUSSION}

The phytotoxicity experiment indicated that dillapiol at $99.5 \%$ was highly toxic against $C$. sinensis, independently of the dilution used. Thus, to facilitate the use of dillapiol at a high purity (99.5\%), the development of new formulations would be required to mitigate this problem.

The treatments with the OPA were highly effective (mortality $>90 \%$ as soon as 1 DAA) for the control of D. citri nymphs in topical applications, presenting similar efficacy to imidacloprid, a widely used and effective active ingredient for control of $D$. citri. These promising results revealed its great potential for the management of this insect vector and were consistent with other studies showing that nymphs are generally sensitive to botanical insecticides. ${ }^{10,33}$ The toxicity of the adjuvant $(0.025 \%)$ to nymphs observed in this study (approximately 50\% mortality) corroborated the results of Srinivasan et al. ${ }^{34}$ Although these authors used a fivefold lower concentration than the one tested in our study $(0.005 \%)$, the higher mortality can be attributed to the application method used by them, which involved immersion of nymph-infested branches in the adjuvant solution.

Regarding the efficacy of topical application against adults, we observed that various concentrations of dillapiol in OPA at different dilutions were effective for control of $D$. citri (mortality between 70 and 98\%). Other studies showed that neem extract 
at $1 \%$ dilution caused $80 \%$ mortality and reduced the number of adults on leaves by up to fourfold compared with untreated areas. $^{12,13}$ Similarly, a $1 \%$ dilution of $D$. alba extract reduced the number of $D$. citri adults on leaves by up to fourfold compared with untreated areas. ${ }^{13}$ Efficacies of $P$. aduncum extract against adults of the sucking insects Aetalion sp. and E. herus of 80 and $100 \%$, respectively, have been reported after topical application at a dose of 3 and $8 \%$ respectively. ${ }^{24,33}$

It is important to emphasise that in our study we used the essential oil obtained by fractional rectification, which allows more accurate qualitative and quantitative profiling and normally has greater stability than botanical extracts. The major compounds (terpenes and terpenoids, and aromatic and aliphatic constituents) usually determine the biological properties of this essential oil. However, the activity of the major components might be modulated by other smaller molecules, ${ }^{35}$ such as apiol and myristicin, that occur in minor quantities and can exert additive or even synergistic insecticidal effects on known insecticidal compounds such as dillapiol. ${ }^{18,22,36}$ Because $D$. citri is an insect vector, its management requires frequent foliar insecticide spraying and the use of a reduced number of active ingredients with different modes of action, which can lead to selection of a psyllid population resistant to the insecticides commonly used for their control. ${ }^{37,38}$ Therefore, searching for new active ingredients to be used in rotation to control this insect vector is a constant need.

The OPA is mainly composed of dillapiol, ${ }^{14,19,20}$ which has a potential inhibitory activity against the detoxifying enzymes responsible for the elimination of plant metabolites potentially toxic to insects. ${ }^{21,22}$ Previous studies have demonstrated that elevated levels of esterases, glutathione S-transferase and cytochrome P450 enzymes are responsible for the detoxification of insecticides in $D$. citri nymphs and adults, and these enzymes are associated with lower susceptibility of this insect to insecticides frequently used for its control. ${ }^{39-41}$

Studies have demonstrated that dillapiol acts as a potent synergist of synthetic and botanical insecticides in agricultural pest control. ${ }^{42,43}$ Liu et al. ${ }^{43}$ observed that dillapiol in combination with pyrethrum extract purified from Chrysanthemum cinerariifolium was 9.1-fold more effective for the control of Leptinotarsa decemlineata (Say) larvae resistant to insecticides including pyrethrum. Mukerjee et al. ${ }^{44}$ showed that acyl derivatives of dihydrodillapiol have a synergistic activity towards pyrethrum against Tribolium castaneum (Herbst.), with a synergism factor ( $\mathrm{LC}_{50}$ for pyrethrum/LC $\mathrm{L}_{50}$ for pyrethrum plus synergist) of 2.3-4.0. Shankarganesh et $a l .{ }^{45}$ reported that dihydrodillapiol combined with pyrethroids caused significant reduction in resistance of Spodoptera litura (F.), which is currently resistant to cypermethrin, lambda cyhalothrin and profenophos. Tomar et al. ${ }^{46}$ observed that a mixture of pyrethrum and dillapiol synthesised by chemical transformation (1:5) showed a synergism factor varying from twoto fivefold when compared with pyrethrum alone against $T$. castaneum. Thus, essential oils rich in dillapiol might help to reduce resistance in $D$. citri populations, because this active ingredient can potentially inhibit the activity of detoxifying enzymes in insects. However, further studies are required to prove this hypothesis. The present study has clearly demonstrated the high efficacy of the OPA in the control of $D$. citri. As the mode of action is unlike that of insecticides commonly used in citriculture, it could be used in rotation for effective management of $D$. citri. The results of this study will contribute to the future adoption of dillapiol-rich oils as a control strategy of $D$. citri.

\section{ACKNOWLEDGEMENTS}

We are grateful to the Fundo de Defesa da Citricultura (Fundecitrus) for a grant to the first author, to the Empresa Brasileira de Pesquisa Agropecuária (Embrapa) for financing part of the project by means of resources obtained from the National Treasury, to Prof. Dr Edson Rodrigues Filho (LaBioMMi - Laboratório de Bioquímica Micromolecular de Microorganismos/Department of Chemistry, Federal University of São Carlos - UFSCar) for technical support, and for allowing the use of GC-MS for the analyses of essential oils of $P$. aduncum, and to the National Council for Scientific and Technological Development (CNPq) for providing support for this research in the form of aid to research (MCTI/CNPq/Universal, proc. 442926/2014-6).

\section{REFERENCES}

1 Coletta-Filho HD, Targon MLPN, Takita MA, De Negri JD, Pompeu Junior J, Machado MA et al., First report of the causal agent of huanglongbing ('Candidatus Liberibacter asiaticus') in Brazil. Plant Dis 88:1382 (2004).

2 Teixeira DC, Ayres AJ, Kitajima EW, Tanaka FAO, Danet J, Jagoueix-Eveillard $S$ et al., First report of a huanglongbing-like disease of citrus in Sao Paulo State, Brazil, and association of a new liberibacter species, Candidatus Liberibacter americanus, with the disease. Plant Dis 89:107 (2005).

3 Bové JM and Ayres AJ, Etiology of three recent diseases of citrus in São Paulo State: sudden death, variegated chlorosis and huanglongbing. IUBMB Life 59:346-354 (2007).

4 Capoor SP, Rao DG and Viswanath SM, Diaphorina citri Kuwayma, a vector of the greening disease of citrus in India. Ind Agric Sci 37:572-576 (1972).

5 Yamamoto PT, Felippe MR, Garbim LF, Coelho JH, Ximenes NL, Martins EC et al., Diaphorina citri (Kuwayama) (Hemiptera: Psyllidae): vector of the bacterium Candidatus Liberibacter americanus. Proc Huanglongbing - Greening International Workshop, Ribeirão Preto, São Paulo, Brazil, p. 96 (2006).

6 Belasque J, Jr, Yamamoto PT, Miranda MP, Bassanezi RB, Ayres AJ and Bové JM, Controle do huanglongbing no estado de São Paulo, Brasil. Citrus Res Technol 31:53-64 (2010).

7 Miranda MP, Noronha NC, Jr, and Marques RN, Alternativas para o manejo do vetor do greening no Brasil, in Avanços em Fitossanidade, ed. by Baldin ELP, Fujihara RT, Firmino AC, Negrisoli E, Souza ES, Prado EP et al. UNESP/FEPAF, Botucatu, São Paulo, Brazil, pp. 143-163 (2011).

8 Boina DR and Bloomquist JR, Chemical control of the Asian citrus psyllid and of huanglongbing disease in citrus. Pest Manag Sci 71:808-823 (2015).

9 Tiwari S, Mann RS, Rogers ME and Stelinsk LL, Insecticide resistance in field populations of Asian citrus psyllid in Florida. Pest Manag Sci 67:1258-1268 (2011).

10 Weathersbee AAW and Mckenzie CL, Effect of a neem biopesticide on repellency, mortality, oviposition, and development of Diaphorina citri (Homoptera: Psyllidae). Fla Entomol 88:401 -407 (2005).

11 Rao CN and Shivankar VJ, Relative efficacy of certain bio-rational insecticides to citrus psylla (Diaphorina citri). Ind J Agric Sci 81:673-676 (2011).

12 Khan I, Zahid M and Khan GZ, Toxicity of botanic and synthetic pesticide residues to citrus psyllid Diaphorina citri Kuwayama and Chysoperla carnea (Stephens). Pak J Zool 44:197-201 (2012).

13 Khan AA, Afzal M, Qureshi JA, Khan AM and Raza AM, Botanicals, selective insecticides, and predators to control Diaphorina citri (Hemiptera: Liviidae) in citrus orchards. Insect Sci 21:717-726 (2014).

14 Maia JGS, Zoghbi MGS, Andrade EHA, Santos AS, Silva ML, Luz AIR et al., Constituents of the essential oil of Piper aduncum L. growing in the Amazon Region. Flav Fragr J 13:269-272 (1998).

15 Zapata N and Smagghe G, Repellency and toxicity of essential oils from the leaves and bark of Laurelia sempervirens and Drimys winteri against Tribolium castaneum. Ind Crops Prod 32:405-410 (2010).

16 Chu SS, Liu SL, Jiang GH and Liu ZL, Composition and toxicity of essential oil of Illicium simonsii Maxim (Illiciaceae) fruit against the maize weevils. Rec Nat Prod 4:205-210 (2010). 
17 Ogendo JO, Deng AL, Kostyukovsky M, Ravid U, Matasyoh JC, Omolo EO et al., Fumigant toxicity of five essential oil constituents against major stored-product insect pests of food grains. Proc $2^{\text {nd }}$ RUFORUM Biennial Regional Conference - Building Capacity for Food Security in Africa, Entebbe, Uganda, pp. 325-332 (2010).

18 Bernard CB, Arnason JT, Philogene BJR, Lam J and Waddel T, In-vivo effect of mixtures of allelochemicals on the life cycle of the European corn borer, Ostrinia nubilalis. Entomol Exp Applic 57:17-22 (1990).

19 Guerrini A, Sacchetti G, Rossi D, Paganetto G, Muzzoli M, Andreotti E et al., Bioactivities of Piper aduncum L. and Piper obliquum Ruiz \& Pavon (Piperaceae) essential oils from Eastern Ecuador. Environ Toxicol Pharmacol 27:39-48 (2009).

20 Potzernheim MCL, Bizzo HR, Silva JP and Vieira RF, Chemical characterization of essential oil constituents of four populations of Piper aduncum L. from Distrito Federal, Brazil. Biochem Syst Ecol 42:25-31 (2012).

21 Bernard CB, Arnason JT, Philogène BJR, Lam J and Waddell T, Effect of lignans and other secondary metabolites of the Asteraceae on the mono-oxygenase activity of the European corn borer. Phytochemistry 28:1373-1377 (1989).

22 Bernard $C B$, Krishnamurty IHG, Chauret $D$, Durst $T$, Philogène $B J R$, Sánchez-Vindas $P$ et al., Insecticidal defenses of Piperaceae from the Neotropics. J Chem Ecol 21:801-814 (1995).

$23 \mathrm{Li} \mathrm{X}$, Schuler MA and Berenbaum MR, Molecular mechanisms of metabolic resistance to synthetic and natural xenobiotics. Annu Rev Entomol 52:231-253 (2007)

24 Silva WC, Ribeiro JD, Souza HEM and Corrêa RS, Atividade inseticida de Piper aduncum L. (Piperaceae) sobre Aetalion sp. (Hemiptera: Aetalionidae), praga de importância econômica no Amazonas. Acta Amazonica 37:293-298 (2007).

25 Castro RS, Pena MR, Silva NM, Vendramim JD and Costa IB, Atividade ovicida de extratos aquosos de folhas de Piper aduncum $\mathrm{L}$. sobre a mosca-negra-dos-citros, Aleurocanthus woglumi Ashby (Aleyrodidae) em condições de laboratório. Proc 61th Reunião Anual da SBPC, UFAM, Manaus, AM, 2009. [Online]. Available: http://www.sbpcnet.org.br/livro/61 ra/resumos/resumos/4179.htm [4 April 2015].

26 Fazolin M, Estrela JLV, Catani V, Lima MS and Alecio MR, Toxidade do óleo de Piper aduncum L. a adultos de Cerotoma tingomarianus Bechyné (Coleoptera: Chrysomelidae). Neotrop Entomol 34:485-489 (2005).

27 Fazolin M, Estrela JLV, Catani V, Alecio MR and Lima MS, Propriedade inseticida dos óleos essenciais de Piper hispidinervum C. DC., Piper aduncum L. e Tanaecium nocturnum (Barb. Rodr.) Bur. \& K. Shum sobre Tenebrio molitor L., 1758. Ciênc Agrotecnol 31:113-120 (2007).

28 Estrela JLV, Fazolin M, Catani V, Alécio MR and Lima MS, Toxicidade de óleos essenciais de Piper aduncum e Piper hispidinervum em Sitophilus zeamais. Pesqui Agropecu Bras 41:217-222 (2006).

29 Pimentel FA, Pereira JBM and Oliveira MN, Processo de extração de óleo essencial de pimenta longa (Piper hispidinervum). Comunicado Técnico 97, Embrapa, Rio Branco, Acre, Brazil (1998).

30 Adams RP, Identification of essential oils components by Gas Chromatography/Quadrupole Mass Spectroscopy, $4^{\text {th }}$ edition. Allured Publishing Corporation, Carol Stream, IL (2007).
31 Thomazini M and Franco MRB, Metodologia para análise dos constituintes voláteis do sabor. Bol Soc Bras Ciênc Tecnol Aliment 34:52-59 (2000).

32 Barbosa JC and Maldonado W, Jr, AgroEstat - Sistema para Análises Estatísticas de Ensaios Agronômicos. Version 1.1.0.711. Jaboticabal, São Paulo, Brazil (2014).

33 Piton LP, Turchen LM and Butnariu AR, Natural insecticide based-leaves extract of Piper aduncum (Piperaceae) in the control of stink bug brown soybean. Ciênc Rur 44:1915-1920 (2014).

34 Srinivasan R, Hoy MA, Singh R and Rogers ME, Laboratory and field evaluations of Silwet L-77 and kinetic alone and in combination with imidacloprid and abamectin for the management of the Asian citrus psyllid, Diaphorina citri (Hemiptera: Psyllidae). Fla Entomol 91:87-100 (2008).

35 Bakkali F, Averbeck S, Averbeck D and Idaomar M, Biological effects of essential oils - a review. Food Chem Toxicol 46:446-475 (2008).

36 Bizzo HR, Lopes D, Abdala R, Pimentel FA, de Souza JA, Pereira MV et al., Sarisan from leaves of Piper hispidinervum C. DC (Long pepper). Flav Fragr J 16:113-115 (2001).

37 Grafton-Cardwell EE, Stelinski LL and Stansly PA, Biology and management of Asian citrus psyllid, vector of the huanglongbing pathogens. Annu Rev Entomol 58:413-432 (2013).

38 Manejo de resistência de psilídeo de citros a Inseticidas. [Online]. Comitê Brasileiro de Ação a Resistência a Inseticidas, IRAC (2014). Available: http://www.irac-online.org/documents/resistencia-de-psilideodos-citros/?ext=pdf [3 December 2014].

39 Tiwari S, Pelz-Stelinski K and Stelinski LL, Effect of Candidatus Liberibacter asiaticus infection on susceptibility of asian citrus psyllid, Diaphorina citri, to selected insecticides. Pest Manag Sci 67:94-99 (2011).

40 Tiwari S, Pelz-Stelinski K, Mann R and Stelinski LL, Gluathione transferase and cytocrome P450 (general oxidase) activity levels in Candidatus Liberibacter asiaticus-infected and uninfected Asian citrus psyllid (Hemipera: Psyllidae). Ann Entomol Soc Am 104:297-375 (2011).

41 Tiwari S, Gondhalekar AD, Mann RS, Scharf ME and Stelinski LL, Characterization of five CYP4 genes from Asian citrus psyllid and their expression levels in Candidatus Liberibacter asiaticus-infected and uninfected psyllids. Insect Mol Biol 20:733-744 (2011).

42 Tomar SS, Saxena VS, Maheshwari ML, Sarup P and Mukherjee SK, New carbaryl synergists derived from dillapiole. Indian J Entomol 40:113-116 (1978)

43 Liu SQ, Scott IM, Pelletier Y, Kramp K, Durst T, Sims SR et al., Dillapiol: a pyrethrum synergist for control of the Colorado potato beetle. $J$ Econ Entomol 107:797-805 (2014).

44 Mukerjee SK, Walia S, Saxena VS and Tomar SS, New pyrethrum synergists from dihydrodillapiole and furapiole. Agric Biol Chem 46:1277-1283 (1982).

45 Shankarganesh K, Walia S, Dhingra S, Subrahmanyam B and Babu $\mathrm{SR}$, Effect of dihydrodillapiole on pyrethroid resistance associated esterase inhibition in an Indian population of Spodoptera litura (Fabricius). Pestic Biochem Physiol 102:86-90 (2012).

46 Tomar SS, Maheshwari ML and Mukerjee SK, Synthesis and synergistic activity of dillapiole based pyrethrum synergists. J Agric Food Chem 27:547-550 (1979). 